\title{
CORRECTION
}

\section{Correction to: Stability of cryopreserved Polyscias filicifolia suspension cell culture during cultivation in laboratory and industrial bioreactors}

M. V. Titova ${ }^{1}$ - E. V. Popova ${ }^{1}$ (D) N. A. Shumilo ${ }^{1}$ - I. E. Kulichenko ${ }^{1}$ N. D. Chernyak ${ }^{1}$ - I. M. Ivanov ${ }^{1} \cdot$ A. G. Klushin ${ }^{1}$. A. M. Nosov ${ }^{1,2}$

Published online: 11 March 2021

○) Springer Nature B.V. 2021

\section{Correction to: \\ Plant Cell, Tissue and Organ Culture (PCTOC) \\ https://doi.org/10.1007/s11240-021-02030-5}

The last author's name was incorrectly captured in the initial online publication. The original article has been corrected.

Publisher's Note Springer Nature remains neutral with regard to jurisdictional claims in published maps and institutional affiliations.

The original article can be found online at https://doi.org/10.1007/ s11240-021-02030-5.

E. V. Popova

elena_aygol@hotmail.com

1 K.A. Timiryazev Institute of Plant Physiology of Russian Academy of Sciences, Moscow, Russia 127276

2 Faculty of Biology, Lomonosov Moscow State University, Moscow, Russia 119992 